\title{
Development of landscape conservation value map of Jeju island, Korea for integrative landscape management and planning using conservation value of landscape typology
}

\author{
Baysok Jun $^{1}$, Ilkwon Kim ${ }^{1}$, Jihoon Shin ${ }^{2}$, Hyuksoo Kwon ${ }^{\text {Corresp. } 1}$ \\ ${ }^{1}$ Ecosystem Service Team, National Institute of Ecology, Seocheon-gun, Chungcheongnam-do, Korea \\ 2 Department of Landscape Architecture, Dankook University, Cheonan, Chungcheongnam-do, Republic of Korea \\ Corresponding Author: Hyuksoo Kwon \\ Email address: ulmus@nie.re.kr
}

Understanding landscape as a socio-ecological system where systematic interactions occur among diverse ecosystems and human society is necessary for a sustainable landscape and resource management. However, many countries with rapid economic growth, including South Korea, depend on conventional planning and policy decisions to meet increasing demands for the use of specific natural resources. Such resource-oriented planning and policy which neglect considerations for the surrounding landscape can result in conflicts of interest and regulation. We designed a landscape conservation value (LCV) map of Jeju Island, Korea to overcome rising managerial and policy issues with the provision of systematic perspectives of landscape. With a consideration for natural and human-modified characteristics of the landscape, we used landform and land cover data to create fundamental landscape types. Then, the LCV was assigned to each type by a board of landscape experts. Within a study region, we observed relatively high values in registered protected areas and unique landscapes, and areas where high and low values are aligned. The resultant LCV map can identify areas that potentially require an integrated approach to prevent adverse effects caused by a conventional approach. 
1 Development of landscape conservation value map of

2 Jeju island, Korea for integrative landscape

3 management and planning using conservation value

4 of landscape typology

${ }^{1}$ Ecosystem Service Team, National Institute of Ecology, 33657 Seocheon-gun, 9 Chungcheongnam-do, Korea

${ }^{2}$ Department of Landscape Architecture, Dankook University, 31116 Cheonan,

Baysok Jun ${ }^{1}$, Ilkwon Kim ${ }^{1}$, Jihoon Shin², Hyuksoo Kwon ${ }^{1}$ Chungcheongnam-do, Korea Corresponding Author: Hyuksoo Kwon ${ }^{1}$

1210 Geumgang-ro, Maseo-myeon, Seocheon-gun, Chungcheongnam-do, 33657, Korea Email address: ulmus@nie.re.kr

\section{Abstract}

Understanding landscape as a socio-ecological system where systematic interactions occur among diverse ecosystems and human society is necessary for a sustainable landscape and resource management. However, many countries with rapid economic growth, including South Korea, depend on conventional planning and policy decisions to meet increasing demands for the use of specific natural resources. Such resource-oriented planning and policy which neglect considerations for the surrounding landscape can result in conflicts of interest and regulation. We designed a landscape conservation value (LCV) map of Jeju Island, Korea to overcome rising managerial and policy issues with the provision of systematic perspectives of landscape. With a consideration for natural and human-modified characteristics of the landscape, we used landform and land cover data to create fundamental landscape types. Then, the LCV was assigned to each type by a board of landscape experts. Within a study region, we observed relatively high values in registered protected areas and unique landscapes, and areas where high and low values are aligned. The resultant LCV map can identify areas that potentially require an integrated approach to prevent adverse effects caused by a conventional approach.

\section{Introduction}

A landscape is comprised of diverse physical products that result from interactions between different phenomena and human behaviors within an ecosystem. Through perception and recognition by humans, a landscape is a single system consisting of natural scientific, social scientific, and anthropological dimensions (Zonneveld 1989; Zube et al. 1982). Thus, landscapes require a complex study of its influences, such as the observer's experience, age, and personality traits, as well as spatial elements, such as the observer's position and the surrounding 
40

41

42

43

44

45

46

47

48

49

50

51

52

53

54

55

56

57

58

59

60

61

62

63

64

65

66

67

68

69

70

71

72

73

74

75

76

77

78

79

80

81

82

83

84

not all landscapes are managed in the same manner as there are many countries which utilize their national territory as a resource due to rapid development of technologies and economic growth.

It has been commonly agreed that rapid growth of population, economy, dynamic of land use, and land cover changes cause landscape fragmentation (Dewan et al. 2012; Li et al. 2010; Opdam et al. 1993; Su et al. 2014). A majority of the landscape has been under-controlled by humans, and during the last century, conventional approaches for maximizing productivity and use of resources induced devastation of diverse landscapes (Denier et al. 2015; Scherr \& Wertz 2019). In many developing and rapidly developed countries with evolving technologies and growing economies, in the management of resources such as timber, water, land for agricultural goods, and settlement, minerals have been secured as their priority to meet their demand. Thus, resource-oriented management has been implemented by pairing specific resources with different ministries or sectors of the government independently, rather than considering a whole landscape which consists of complex interactive ecosystems such as watersheds, pollination networks, habitats, and social flows (Denier et al. 2015). Such sectoral management can possibly result in different policy goals and regulations within the same area, which could induce conflict among diverse stakeholders during utilization and conservation of the land.

Regarding Aichi target 11 announced at the 10th Conference of the Parties to the Convention on Biological Diversity, 193 countries were assigned to expand protected areas by up to $17 \%$ of the country's terrestrial area by 2020 . Eventually, 15 out of the top 20 countries in growth rate of GDP (Gross Domestic Product) per capita from 1990 to 2019 fulfilled their goal (UNEP-WCMC 2020). Despite their fulfillment, 11 out of the 15 rapidly growing countries, such as China, Sri Lanka, South Korea, and eight others, did not achieve neither the global level of Protected Area Management Effectiveness (Hockings et al. 2006) nor the connectivity of the protected areas (Saura et al. 2019). Whereas, slow growing countries, such as the United Kingdom, the Seychelles, the Bahamas, Botswana, Germany, the Congo, and others, achieved the rate of either management effectiveness or connectivity far beyond the global level.

To manage a country's territory with considerations for biodiversity, sustainability, and resilience towards climate change, systemic resource management is critical. In this context, landscape is a socio-ecological system consisting of natural and human-modified ecosystems which is influenced by diverse land use approaches such as ecological, historical, political, economic, and cultural process and activities (Denier et al. 2015). European countries and other developed countries, typically the United Kingdom, have adapted and developed landscape approaches in a way that respects systematic interactions among diverse ecosystems and human society by establishing local autonomy from the 1970s (Golley 1993; Selman 2006). The approach evolved from landscape evaluation in the 1970s, which was adapted to preserve the best and leave the rest to support environmental impact assessment by establishing a local autonomy system. Then, to complement landscape evaluation, landscape assessment was introduced in the 1980s to assess landscape based on its quality and quantity. Eventually, landscape character assessment was introduced in the 1990s which was adapted by more than 14 European countries during the European landscape character assessment initiative from 2003 to 2005 (Fairclough \& Macinnes 2003; Wascher 2005). Landscape character assessment is the most current and critical landscape approach used for policy and decision making as of today, and it involves landscape resource data collection and analysis, and assessment of landscape character based on its aesthetical, psychological, and social values (Fairclough \& Macinnes 2003). 
85

86

87

88

89

90

91

92

93

94

95

96

97

98

99

100

101

102

103

104

105

106

107

108

109

110

111

112

113

114

115

116

117

118

119

120

121

122

123

124

125

126

127

128

129

Like other abovementioned developing and rapidly developed countries, Republic of Korea's GDP per capita quintupled from 1990 to 2019 and ranked as the 18th fastest growing country out of 155 countries (UNEP-WCMC 2020). In Korea, the rapid growth of economies and technologies began after the Korean war (1950-1953) which mainly depended on quantitative growth of the national power. Therefore, the sectoral approach of managing specific resources remains the same, whereas the quality and interactions within the environment were neglected. With growing concern for the environment, various acts and legislations have been established and revised mainly by the Ministry of Environment, Ministry of Land, Infrastructure and Transport (MLIT), and Ministry of Agriculture, Food and Rural Affairs over the decades.

To enhance regulatory standards for managing landscapes, the MLIT established landscape legislation in 2007. However, the legislation was not compatible with other acts or legislation due to a lack of practical and reasonable standards for a wide range of stakeholders which weakened its regulatory characteristics (Jung 2018). In 2013, the landscape legislation was revised such that the MLIT minister must establish the master plan of national landscape policy every 5 years, and the mayors of cities with a population over 100,000 have to establish a mandatory regional landscape plan. Since then, the number of landscape projects has grown continuously with 100 projects implemented in 2015, 139 projects in 2016, and 182 projects in 2017 , indicating there is a significant amount of landscape-related data accumulating nationwide (Lee 2018).

Hitherto, different municipalities and ministries have spent significant parts of their budget on landscape resource surveys. However, due to a lack of compatibility of landscape classification and evaluation between ministries' policies and municipalities' regulations, landscape resource data could not be utilized for multi-dimensional planning. Like landscape resources, zonings implemented by different ministries and municipalities resulted in conflicts. Managerial conflicts tend to occur where the boundaries of the zoning falls under different jurisdiction, where one is managed for development and the other is managed for strict conservation. Therefore, for more systematic management of fragmented landscapes caused by policy-oriented zoning, there needs to be a fundamental framework compatible with all jurisdictions that can comprehend a whole national territory and prioritize susceptible areas for enhanced management.

In terms of land use planning, landform is proven to have a great impact on natural processes of landscape as it provides distinct visual borders and homogeneous visual shaping throughout their expanse (Martín Duque et al. 2003) and is one of the central variables in the landscape characterization process (Simensen et al. 2018). Despite its significant impact on natural processes, landform has been neglected in the majority of zoning processes in Korea, whereas land cover, which includes vegetation, settlement, and human induced factors (HoltJensen 2018), has been independently used for zoning. Considering the fact that humans are characterized as an agent of change in the physical and biological characteristics of the landscape (Zube 1987), land cover is a substantial variable as it simply represents the current phenomenon of land except it does not show the continuity and naturalness of the land beneath the cover. In other words, landform can be regarded as the physical 'skeleton' of the landscape while land cover, consisting of soils and vegetation, mostly provides the 'flesh' on the bones (Tudor 2014). Therefore, to deal with the current zoning issues and increasing complaints by residents related to separate landscape management, a verification of the connection between social and natural phenomena should be carefully considered. To verify the connection between social and natural 
130 phenomena, landform data containing continuity and naturalness characteristics can

131

132

133

134

135

136

137

138

139

140

141

142

143

144

145

146

147

148

149

150

151

152

153

154

155

156

157

158

159

160

161

162

163

164

165

166

167

168

169

170

171

172

173

simultaneously contribute to landscape zoning and planning processes with land cover data.

In this study, to enhance the applicability of the landscape management system, we used landform and land cover data simultaneously to construct a landscape type which is utilized as a fundamental framework for prioritization of susceptible areas based on a landscape conservation value (LCV) assigned by landscape experts.

We set three objectives using the LCV map and the fundamental framework. First, to suggest a sustainable method of managing landscape where landscape types with great conservation value and low conservation value align. Second, to suggest a comprehensive method of integrating preexisting landscape resource data. Third, to introduce the potential impact of using an LCV map to overcome current landscape-related policy issues. Box 1 provides an overview of the key definitions of terms related to landscape.

\section{Materials \& Methods}

\subsection{Study Site}

We selected Jeju Island, Korea as our study site. With an area of $1,864.75 \mathrm{~km}^{2}$, it is the largest island in Korea and is located in the middle latitudes of the north-west Pacific, the geographical midway between Korea, Japan, and China (Fig. 1).

\section{Figure 1:}

Jeju island is globally recognized for its unique landscape formed by volcanic eruptions between 1.8 million and several thousand years ago. The island contains various recognized resources, including the Halla-san National Park $\left(152.94 \mathrm{~km}^{2}, 8.20 \%\right.$ of Jeju Island), Global Geopark $\left(1,847 \mathrm{~km}^{2}, 99 \%\right)$, Ramsar Wetlands $\left(2.08 \mathrm{~km}^{2}, 0.11 \%\right)$, the core and buffer zones of the biosphere reserve $\left(287.30 \mathrm{~km}^{2}, 15.41 \%\right)$, and a natural world heritage site $\left(94.75 \mathrm{~km}^{2}\right.$, $5.08 \%$ ) which is designated due to its significant scenic and geological value based on outstanding universal value approved by UNESCO (Woo et al. 2013). However, to respect geographical advantages, and the local, historical, and social potentials of the island, the Korean government designated the island as a Special Self-Governing province to establish a Free International City by alleviating administrative regulation and applying an international standard in 2006. Since then, there has been an increasing number of reports insisting that the landscape is exposed to various threats due to over-tourism and developments supporting international exchange. Presently, Jeju Island receives approximately 15 million annual visitors that hope to experience the outstanding ecological and cultural value of the island. The number of visitors is continually increasing and is estimated to reach 45 million in 2035, leading to concerns about landscape damage as a result of over-tourism (Mehmood et al. 2019). Furthermore, alleviated regulation for the Free International City is allowing tremendous speculation in real estate by foreign investors which resulted in irregular changes of land cover and deformation of the unique volcanic landform of Jeju Island. Therefore, analysis of the land cover pattern and discontinuity of the landform is a critical approach for conservation of Jeju Island.

\subsection{Materials}

\subsubsection{Land cover map}

PeerJ reviewing PDF | (2020:10:53761:2:0:NEW 13 Apr 2021) 
174

175

176

177

178

179

180

181

182

183

184

185

186

187

188

189

190

191

192

193

194

195

196

197

198

199

200

201

202

203

204

205

206

207

208

209

210

211

212

213

214

215

216

217

218

219

A land cover map is an environmental theme map best reflecting the current status of a ground surface which is an important factor that affects biodiversity, ecosystem health, and the integrity of protected areas (Hansen \& DeFries 2007; Jones et al. 2009; McKinney 2002). A land cover map consists of both biotic and abiotic features, most often representing human influence on the landscape such as settlement (Holt-Jensen 2018; Simensen et al. 2018) and its vegetation. It represents the natural response to the physical driver controlling the environment, such as landform (Sayre et al. 2014). Thus, land cover is defined as an interactive result of cultural and biophysical phenomena (Mücher 2009), while proving an extrapolation framework for in-situ data on environmental themes of concern (Jones 2008). Land cover has been used as an essential feature for a wide range of landscape characterization studies using holistic, biophysical landscape, and a combination of both concepts with different approaches and perspectives (Simensen et al. 2018; Walz \& Stein 2014).

Created by the Korean Ministry of Environment, the land cover maps were produced in three different level classes with the purpose of enhancing the efficiency and scientific nature of policy making. The large-class is drawn at a regional scale of 1:50,000 with 7 classification items, the middle-class is at scale of 1:25,000 with 22 classification items, and the detailed-class is at scale of 1:5,000 with 41 classification items. In this study, we used the large-class land cover map with 7 classification items as the purpose of this study is to prioritize areas for an enhanced empirical approach for more sound landscape management, rather than evaluating landscape with reference to detailed land classification items. The large-class land cover map is similar to the Coordination of Information on the Environment (CORINE) concept used by the Europe Environment Agency (EEA); however, it has been modified to suit the characteristics of a peninsula in East Asia. The Korean Ministry of Environment has been monitoring and recording changes in land cover nationwide since 1998. With technological development, the land cover data have been updated more frequently and improved with greater precision and accuracy. To determine the land cover of Jeju Island, we used revised data from 2016, as shown in Table 1.

\section{Table 1:}

\subsubsection{Landform map}

The nine-unit landscape model (NULM) differentiates soil-landscape units into nine types by determining the spatial distribution and correlation between the topography and soil, based on the movement of energy, water, and substances in the land surface (Conacher \& Dalrymple 1977; Dalrymple 1968; Park 2004). Previous studies using the NULM had issues with objectivity as the classified soil-land surfaces were based on qualitative descriptions. To resolve these issues, Park (Park 2004) presented a soil-land categorization method using a digital elevation model (DEM) and spatial analysis techniques. With this method, Park recategorized the landforms in South Korea according to their topographic characteristics, including interfluve, summit, shoulder, fall face, backslope, footslope, toeslope, and channel. Shoulder, fall face, backslope, footslope, and toeslope denote erosional slopes, steep slopes with a gradient $\geq 45^{\circ}$, slopes with similar levels of erosion and deposition, depositional slopes, and flat land near waterways, respectively. Summit refers to convex slopes at the tops of mountains and stream refers to waterways, but also appears in regions with little or no distribution of other land surface types (Park 2004). Landform was also categorized into either mountainous or flat land according to characteristics of flat land and footslopes in the lower parts of slopes (Lee et al. 2015; Park 
2004). Here, landforms were categorized using the upslope contributing area and surface curvature in a grid cell through spatial analysis with NULM. (Park 2004). Upslope contributing areas, which assess the potential for movement of materials, were calculated according to the following equation:

$$
\mathrm{AS}=\left(\frac{1}{\mathrm{~b}}\right) \sum_{i=1}^{n} p_{i} \times A_{i}
$$

(1)

Here, the upslope contributing area (AS) was obtained by calculating the product of the area $\left(\mathrm{A}_{\mathrm{i}}\right)$ and the potential inflowing water $\left(\mathrm{p}_{\mathrm{i}}\right)$ for each upslope cell (i), calculating the sum of the products across all upslope cells (where $\mathrm{n}$ is the number of upslope cells), and then dividing this sum by the width between contour lines, which was estimated to be the same as the cell size (b). Surface curvature was calculated using Equation 2, which reflects the convexity/concavity and gradient of the surface.

$$
C_{s}=\left(\sum_{i=1}^{n}\left(Z_{i}-Z_{n}\right) / d_{i n} / n\right)
$$

(2)

Surface curvature $\left(\mathrm{C}_{\mathrm{s}}\right)$ was determined by first calculating the difference between the elevation of a cell $\left(Z_{i}\right)$ and its surrounding cells $\left(Z_{n}\right)$, divided by the distance between the cells $\left(\mathrm{d}_{\text {in }}\right)$, summing all the numbers of surrounding cells, and then dividing by the total number of cells (n). The AS was obtained using the 'dynatopmodel' package (Metcalfe et al. 2018) and the surface curvature was obtained by the 'spatialECO' package (Evans 2020) in R software.

Landform was categorized according to the slope and correlation between the calculated upslope contributing area and surface curvature. In this study, DEM was used at a resolution of $30 \mathrm{~m}$ to calculate the upslope contributing area and the surface curvature. We first categorized landforms based on the study by Park (2004). Then, we recategorized the landforms according to the first expert survey, which suggested landform classes of: "summit", shoulder as "shoulder", backslope and fall face as "slope", footslope as "mild slope", toeslope as "flat land", and stream as "channel" to enable a clearer visual distinction of landforms (Fig. 2).

\section{Figure 2:}

\subsubsection{Landscape types}

Landscape classification that is based on clear standards allows people to broadly accept the diverse properties of landscapes and has been widely recognized to improve communication for policies and research (Brabyn 2005; Mücher et al. 2010). In this study, landform and land cover, referred to as landscape units, underwent a thematic overlaying process and resulted in 35 comprehensive landscape types of Jeju Island. The comprehensive landscape types provide a brief idea of the properties of landscapes while considering biophysical dimensions, humanaesthetic dimensions, and user participation and policy dimension (Groom 2005) prior to conducting an expert knowledge-based landscape survey to evaluate LCVs.

\subsection{Methods}

\subsubsection{Preparation of Landscape types}


262

263

264

265

266

267

268

269

270

271

272

273

274

275

276

277

278

279

280

281

282

283

284

285

286

287

288

289

290

291

292

293

294

295

296

297

298

299

300

301

302

303

304
In this study, to identify top priority areas for enhanced landscape management as an initial stage, three rounds of FGI (Focus Group Interview), field investigation, and two rounds of expert survey were conducted (Fig. 3).

\section{Figure 3:}

The participants of the FGIs were the editorial board of the Korea Landscape Council and each round covered different topics. The first round was used to define limitations and issues related to the current landscape management of Korea and special issues within a research site. The second round was used to select an appropriate approach for landscape management of Korea. Throughout the second round of the FGI, the literature on advanced landscape managements of other countries and its applicability to Korea were reviewed, which eventually resulted in the consensus to form a landscape typology of the research site as a start. The third round was used to select appropriate variables to form landscape types based on spatial data availability, data scale suitability, reliability, data typology availability, regeneration interval, spatial continuity, and noticeability which resulted in choosing land cover and landform.

Once land cover and landform classifications were converted to a raster with a $30 \mathrm{~m}$ cell size and overlaid, it was possible to build a matrix with 35 different landscape types and verify locations of every landscape type using ArcGIS 10.5. After identifying the location of different landscape types, we visited the study site, Jeju Island, in preparation for the expert survey and to aid the understanding of the survey respondents. On site, we gathered materials consisting of four representative images for each of the 35 landscape types and descriptions of each class of landform and land cover.

\subsubsection{Expert Survey for setting conservation value of each landscape type}

To assign conservation value to each landscape type, two rounds of expert knowledge-based survey were conducted with the support of 13 board members consisting of three landscaperelated industry workers with PhDs, six academics, and four researchers. Two rounds of survey were designed to prevent outliers, as having board members to evaluate 35 different landscape types at first glance without any criteria allows for great uncertainty. The first survey was designed to fully reflect the expert landscape knowledge of the board with clear key research points, the nature and construction process for classification of each variable, specific explanations for each of the classifications, and the representative images taken during the field investigation. Prior to evaluating the conservation value of each landform and land cover classifications, the board members were instructed to comprehensively consider six factors (representativeness, specificity, diversity, rarity, irreproducibility, and educational value) based on their knowledge and experience, as shown in Box 1.

The six factors were derived from the geomorphological landscape section of the National Natural Environment Survey guidelines (Cha et al. 2019) and are considered as important criteria for a wide range of landscape and environmental value assessment studies (Erikstad et al. 2008; Solecka 2018). For example, 'representativeness' and 'uniqueness' have been used as criteria to assess perceptual and aesthetic landscape values (Smith \& Theberge 1986) when evaluating both cultural (Risbøl et al. 2000; Utredninger 1983) and natural heritages (Andersson \& Löfgren 2000; Ratcliffe 2012; Rudberg \& Sundborg 1975). 'Diversity' has been considered when measuring aesthetic values of landscape based on its complexity, land cover contrast, and diversity (Frank et al. 2012; Frank et al. 2013) for both cultural (Risbøl et al. 2000) and natural

PeerJ reviewing PDF | (2020:10:53761:2:0:NEW 13 Apr 2021) 
305 heritages (Andersson \& Löfgren 2000; Gonggrijp 1981; Ratcliffe 2012). 'Rarity' is one of the 306 most common criterion when valuing vulnerable areas that are under pressure (Erikstad et al.

307

308

309

310

311

312

313

314

315

316

317

318

319

320

321

322

323

324

325

326

327

328

329

330

331

332

333

334

335

336

337

338

339

340

341

342

343

344

345

346

347

348

349

350 2008) in both cultural (Risbøl et al. 2000) and natural heritage contexts (Andersson \& Löfgren 2000; Gonggrijp 1981; Ratcliffe 2012; Rudberg \& Sundborg 1975). In Korea, 'irreproducibility' has commonly been used to evaluate only geographical and landscape value (Kim 2009; Seo 2013). However, Price (1976) has stated that the degree of irreproducibility is associated with visitor satisfaction with the character of the landscape as people tend to value places with an unspoiled state. 'Educational Value' has been used in several studies to assess the cultural value of landscape (Brown \& Raymond 2007; Brown \& Reed 2000; Smith \& Theberge 1986) and has been used to measure cultural (Risbøl et al. 2000) and natural heritage (Andersson \& Löfgren 2000; Gonggrijp 1981).

\section{BOX 1:}

These factors were used to standardize the perception of the board members as they have been widely used by landscape researchers and managers of Korea (Jeon et al. 2013; Ju \& Woo 2019; Kim 2009; Lee 2017; Seo 2013). The board members evaluated the conservation value of seven classifications of land cover and six classifications of landform using a Likert scale-based survey (1: Very low, 3: Standard, 5: Very high). To assign the weights (importance), a pairwise comparison survey was conducted where respondents were asked to select either "Very Important," "Important," "Merely Important," "Somewhat Important," or "Same" for each type of landform and land cover. Finally, respondents were given the opportunity to provide their opinions on the research methodology and level of understanding and imaging of six landform and seven land cover classifications.

Since an intention of the second round of the FGI was to have the same 13 respondents to evaluate the conservation value of 35 landscape types, the second survey was designed based on the results of first survey. To prepare the second FGI, we examined the results from the first survey and decided to simplify the landform types from six to five. We also rephrased text to improve terminology comprehension. The individual experts' weights for each variable were applied to their ratings, derived from the first survey. The weights were applied by multiplying the relevant rating by a factor of 1.75 for "Very Important," 1.5 for "Important," 1.25 for "Merely Important," and 1 for "Same." After applying the individual experts' weights, the landform and land cover type scores were multiplied and re-calculated on a scale of 1-10. The group's mean rating for each landscape type was calculated using the same method. In the second survey, images representing each landscape type (Table S3) were provided, and the experts were instructed to refer to their own ratings and the overall ratings in the first survey while considering the six factors.

\subsubsection{Mapping landscape conservation}

After the final survey results were collected, the mean LCVs were derived for the 35 total combinations of landscape types and were re-calculated on a scale of 1-10. To apply and map the mean LCV, each cell was assigned a matrix score. The borders of the culturally and ecologically important Ramsar sites, national scenic sites, Oreum with approved landscape quality, biosphere reserve, urban natural park areas, natural monument, national park, Gotjawal, and natural world heritage site were overlaid (Fig. 4). The mean LCV and standard deviations were calculated for the cells pertaining to each site, and these values were compared with the mean for the whole of Jeju Island. 
351

352

353

354

355

356

357

358

359

360

361

362

363

364

365

366

367

368

369

370

371

372

373

374

375

376

377

378

379

380

381

382

383

384

385

386

387

388

389

390

391

392

393

394

395

\section{Figure 4:}

To prioritize susceptible areas for enhanced management, the spatial variance of LCV among every single cell assigned with a different landscape type was analyzed using focal statistics in ArcGIS 10.5. Thereby, the standard deviation of each cell and those of the surrounding cells was obtained.

\section{Results}

\subsection{Geographical Distribution of Landscape Type Areas}

Landscape units, comprising land cover and landform, were separately classified, and their proportions within the research site were overviewed prior to the thematic overlaying process. The land cover of Jeju Island was split into 7 categories (Fig. 5). 'Developed Area', also known as non-arable land (comprising 13,365.6 ha (7.23\%) of the total study area), consists of paved infrastructure for transportation, residential area, industrial, commercial, entertainment, and public facilities. 'Agricultural area' $(65,608.3$ ha (35.49\%)), consists of rice paddies, fields, vinyl greenhouse, orchards, and other arable land. 'Forest area' $(64,181.3$ ha (34.7\%)), consists of broadleaf tree forest, conifer tree forest, and mixed stand forest. 'Grassland' $(35,097.4$ ha $(19.0 \%))$, is comprised of natural and artificial pasture. 'Wetland' (724 ha $(0.39 \%))$ is comprised of inland and coastal wetland. 'Barren land' $(5,386.7$ ha $(2.91 \%))$ is comprised of natural and other barren land. 'Open water' $(492.8$ ha $(0.27 \%))$, is comprised of inland water and sea water.

\section{Figure 5:}

The landform map shows that 'Flat land' mainly occupied $122,778.1$ ha (66.4\%) of the study area, surrounding Halla-san mountain the volcanic origin of the island (Fig. 6). 'Summits' (6,610 ha $(3.57 \%)$ ) which are randomly scattered in the form of small points delineating volcanic cones created by eruptions. 'Sloped lands' $(31,534.6$ ha $(17.07 \%))$ formed around lava cones and are mainly distributed across Halla-san mountain. 'Shoulder' (20,715 ha (11.21\%), in the form of strips, originated from the peak of Halla-san mountain. 'Channel' $(3,129.9$ ha $(1.69 \%))$, in the form of strips, formed a network in the 'Sloped lands.'

\section{Figure 6:}

As a result of the thematic overlaying process, Figure. 7 shows the major landscape types occupying over $5 \%$ of the study area. Flat agricultural land occupies the largest area $(582.20$ $\left.\mathrm{km}^{2}, 31.52 \%\right)$, followed by flat forest $\left(301.75 \mathrm{~km}^{2}, 16.33 \%\right)$, flat barren land $\left(267,16 \mathrm{~km}^{2}\right.$, $14.46 \%)$, sloped forest $\left(199.77 \mathrm{~km}^{2}, 10.81 \%\right)$, flat developed land $\left(118.97 \mathrm{~km}^{2}, 6.44 \%\right)$, and forest over a shoulder $\left(102.56 \mathrm{~km}^{2}, 5.55 \%\right)$. The remaining 29 landscape types accounted for $14.89 \%$ of the study area, and forests formed over a summit, shoulder, slope, and channel occupied nearly $0 \%$ of the research site (Table S2).

\section{Figure 7:}

As shown in Figure 8, the technique developed here is a simple and comprehensive approach that enables the identification of representative landscape types and the location of 
396

397

398

399

400

401

402

403

404

405

406

407

408

409

410

411

412

413

414

415

416

417

418

419

420

421

422

423

424

425

426

427

428

429

430

431

432

433

434

435

436

437

438

439

440

unique or rare landscape types. Based on the landscape type map, each landscape type was investigated by the research team. Table S3 presents images collected for each landscape type.

\section{Figure 8:}

\subsection{Landscape Conservation Value}

Throughout the expert survey, the LCVs of each landscape type were obtained and normalized on a scale of 1 to 10. Landscape types with the highest conservation value were wetland formed over a summit and open water over a summit (10), followed by forest formed over a summit (9.41), wetland within channel (8.57), open water filled in channel (8.39), and forest formed along the channel (8.23) (Table 2, Table S1). The landscape type with the lowest conservation value was given to flat barren land (1), followed by flat developed area (1.43), hilly barren land (1.59), and hilly developed area (1.68). In Table 2, the landscape conservation value trends are presented with the highest in the lower right corner to the lowest scores in the upper left corner.

\section{Table 2:}

\subsection{Landscape Conservation Value Map}

Figure 9 shows the distribution of 35 different landscape types with an application of normalized Landscape Conservation Values obtained throughout the survey. In Figure. 9, high ratings significantly appear (black) within the boundaries of Jeju Island's famous landmark, such as Halla-san National Park labeled as 3 in Figure 9, as well as the other protected regions shown in Figure. 8. The oreums labeled as 1 in the figure, a common name for a volcanic cone in Jeju Island (Nam et al. 2019), are visible as small, scattered circular shapes with high scores; Gotjawal, labeled as 5 in the figure, is a uniquely formed forest vegetation found on lava terrain (located at the eastern and western parts of Jeju Island (Kang et al. 2013). On the other hand, developed areas such as roads and the central town of Jeju city and Seogwipo city appear to have relatively low landscape conservation value.

\section{Figure 9:}

The mean score of every cell in each of the designated areas and whole research site was calculated (Table 3). The values for designated areas, especially the National Park, 'Oreum', Biosphere Reserve, and Ramsar site were far higher than the mean for the overall study site and showed relatively lower standard deviations compared to the whole research site, as shown in Table 3.

\section{Table 3:}

Figure. 10 presents areas potentially susceptible to various human activities which are raster cells with the top $20 \%$ (1.74) standard deviation. Through comparison with satellite images, it was found that most of these areas are mountain trails, paved roads through the forest and along streams, industrially and commercially developed areas, residential areas, and tourist spots with a significant amount of paved parking lots which are widely exposed to human activities. 
442 Figure 10:

\section{Discussion}

\section{4.1 Management of Susceptible Area}

445

446

447

448

449

450

451

452

453

454

455

456

457

458

459

460

461

462

463

464

465

466

467

468

469

470

471

472

473

474

475

476

477

478

479

480

481

482

483
In this study, the LCV map provides the location of landscape type with both high and low conservation value in the form of a raster dataset. Landscape types with high conservation value are wetland, open water, and forests formed over summits or streams. These types are unique or provide wildlife habitat and opportunities for natural leisure experiences, such as fishing, strolling, and hunting. However, landscapes with low conservation value are flat land, hilly barren land, and hilly developed land. These types provide comparably greater opportunities for the development of commercial plots, residential areas, parking lots, and roads.

The natural and the human systems develop and expand territories through different processes and the long-term result leaves significant changes in land cover and landforms. However, due to demographics, globalization, and growing economies, humans tend to influence the landscape quicker than nature can adapt (Millspaugh \& Thompson 2009). Furthermore, with evolving technologies, more landscape types are exposed to human development, as evidenced by the increase of residential buildings in wet and rocky areas (LaGro Jr James 1996). Moreover, human impacts such as landscape fragmentation and land ownership parcelization result in land subdivision along various ecosystems, such as small lakes, rivers, and forest areas, which had formerly not been considered for human uses (Millspaugh \& Thompson 2009). Therefore, landscapes with significant conservation value are becoming increasingly susceptible to human developments. Considering that the research site is a globally recognized tourist destination for its natural landscape and the policy is focused on the enhancement of international exchanges, there has been an increasing demand for natural and cultural experiences and opportunity for tourism businesses. Furthermore, as real estate investment of the research site is available for foreigners, a land ownership has been parcelized for development which resulted in conflicts of stakeholders' interest. Therefore, land outside of designated areas and permitted for development while being adjacent to great natural landscape can be a great target for tourism investment. This will potentially either positively or negatively influence adjacent natural landscape, depending on the landowner's strategy, policy adjustment, and conservation budget.

Like cracks in the wall of interconnected ecosystem, some of revealed susceptible areas within the designated area may have been well managed with the support of a conservation budget, whereas some privately owned areas are easily exposed to development and domination as the area provides great opportunities for tourism investment. The development, without considering the surrounding landscape, can negatively influence interaction networks of different landscape types ecologically and biophysically, such as connectance or nestedness (Astegiano et al. 2015). Thus, the susceptible areas being proposed can be prioritized as critical management areas, and flexible strategies, such as conservancy zoning, where individual landowners cluster development and leave the large proportion of their land in relatively undisturbed forest cover (Millspaugh \& Thompson 2009), cross boundary management (Harper et al. 2006), and reserve based models, should be considered in order to prevent landscape fragmentation.

\subsection{Compatibility of LCV Map for Integrating Pre-existing Landscape Resources}


484

485

486

487

488

489

490

491

492

493

494

495

496

497

498

499

500

501

502

503

504

505

506

507

508

509

510

511

512

513

514

515

516

517

518

519

520

521

522

523

524

525

526

527

528

The major function of the LCV is to be compatible for all regions and easily understood. Presently, landscape resource data are continually being collected from diverse perspectives; however, planners and decision makers are limited in their ability to assimilate data that are mutually different in nature. The LCV map is a container for various existing landscape resource data, resulting in its unique ability to produce additional in-depth, high-quality analyses when overlaid with other landscape-related information. The LCV has an objective biophysical basis, and the landscape types are constructed with fundamental variables, meaning that it reflects the fundamental attributes of the landscape. In addition, because land cover and landform apply to the whole surface, excluding the ocean, there are no gaps. Therefore, the LCV map is compatible with any form of landscape-related spatial data (point, linear, or planar) that corresponds to natural, cultural, aesthetic, and perceptual domains. Although the landscape types proposed in this study provide great compatibility with other spatial data and improve communication among different stakeholders, the variation within the landscape types does not reflect an actual phenomenon of a particular landscape area. However, the landscape type system comprises a predictable level of landscape variation which provides a useful reference for the assessment of an individual landscape area's character and properties. It is also possible to compare an assigned value with the conservation value of landscape types. For example, if the summit and open water landscape character, which had the second highest conservation value, is present within the matrix of the region of interest, this area is likely to be visually sensitive, rare, and ecologically exceptional. However, if the LCV map is overlaid with landscape resource data with high recreational value, therapeutic value, sensory experiences, or views, planners or policymakers could consider that this area has both high landscape and high utility values, or even that its unique characteristics suggest that it could be subject to degradation. As another example, flat barren land and flat development areas are likely to be a target for development due to their low aesthetical and ecological value. However, if the flat and barren land were overlaid with existing landscape resource data, one might discover a world heritage site, or symbolic, spiritual, or educational value. Therefore, even if an element with a certain value is located in a landscape type with low LCV, visual sensitivity, and ecological value, by overlaying highly valued landscape resource data, planners and policymakers could anticipate the likelihood of degradation. Additionally, considering the proximity of flat and development land that has already been developed, specific administrative measures could be proposed that account for factors including distance from conservation targets and population influx.

The landform and land cover variables used in this study are important not only for landscape value, but also for various other analyses. Landform types are used in analyses relating to flood hazard vulnerability (Mihu-Pintilie \& Nicu 2019), ecosystems (Swanson et al. 1988), vegetation patterns (Baartman et al. 2018), and ground water recharge (Lukenbach et al. 2019). Meanwhile, land cover types have been used in analyses regarding ecosystem services (Burkhard et al. 2009; Koschke et al. 2012), accessibility of resources in the construction sector (Ioannidou et al. 2015), and urbanization patterns (Dewan \& Yamaguchi 2009). Therefore, the LCV presented in this study is highly compatible with analytical data from several fields. Being able to link different analytical data will contribute to more valid and logical landscape-related decision making because it forms a base of mutual understanding with different stakeholders.

\subsection{Potential Impact of Landscape Conservation Mapping Process on Policy Issues}

Peer] reviewing PDF | (2020:10:53761:2:0:NEW 13 Apr 2021) 
529

530

531

532

533

534

535

536

537

538

539

540

541

542

543

544

545

546

547

548

549

550

551

552

553

554

555

556

557

558

559

560

561

562

563

564

565

566

567

568

569

570

571

572

573

574

As mentioned in the introduction section, there are several landscape approaches, such as landscape characteristic assessment, applied to national policies in many European countries. However, due to rapid growth of the economy and urban sprawl in Korea, there are rising managerial problems related to landscape and conflicts due to non-compatible policies being operated by independent ministries. Currently, there are various types of protected areas, such as national parks, wetland protected areas, and ecological landscape protected areas, designated across the borders of regions countrywide. Hence, depending on regions, the different levels of regulation exist due to different regional planning. The LCV developed in this study offers spatial planners and policy makers the opportunity to analyze a landscape with a more macroscopic and objective perspective, beginning in the initial stages of analysis. The main function of LCV is to help users comprehensively establish landscape types, identify levels of conservation needed, and compare the region of interest with its surroundings. The application of the concept of LCV to any regional planning and national landscape planning can contribute to adjusting differences in the level of regulation and systemic landscape zoning and planning across regions.

\subsection{Limitations of the Study}

The LCV map has three major limitations.

(1) The landform resolution is limited to a minimum of $30 \mathrm{~m}$ cells; thus, areas under $30 \mathrm{~m}^{2}$ cannot be analyzed. Furthermore, even if the quality of data is improved, the LCV is constructed from fundamental elements of landscapes, and therefore, should be applied to the landscape scale. However, if land cover types were further sub-classified according to use, it would be possible to a develop mutual understanding between stakeholders, and the results could be supplemented by overlaying cognitive-based landscape resource data.

(2) There were no lay participants in the FGI or surveys. Therefore, whether the assigned variables would be deemed relatable by members of the general public could not be verified. However, if the opinions of the general public are reflected by considering different stakeholder groups with a larger number of participants in the future, it could support more valid and logical decision making. The survey process proposed in this study is designed specifically for landscape experts. To engage survey participants from a wide range of stakeholder groups, the survey instructions should be revised with clear and definitive explanations for all 6 factors and value criteria to prevent outliers.

(3) There were issues with the design and instructions of the survey which impacted the experts' judgment. To obtain clear and distinct landscape types in the LCV, the landscape types were assigned with numbers ranging from 1 to 10 . However, criteria for 'High', 'Medium', and 'Low' values were not provided which could be a possible reason for outliers in expert judgment. This problem could be solved by setting the value criteria during FGI, with engagement of all the previous participants, and by a literature review. For further studies that involve a broader range of stakeholders, the value criteria should be reflected in the survey instruction in a user-friendly manner to improve objectivity and integrity of the results.

\section{Conclusions}

This study emphasized the current limitations of landscape management in the Republic of Korea, as one of the countries with a rapid growth of economy, and proposed a process of producing an LCV map of Jeju Island as an integrative approach and one of the solutions to deal with current limitations. The limitations are divided landscape management that mainly focuses

Peer) reviewing PDF | (2020:10:53761:2:0:NEW 13 Apr 2021) 
575 on utilization of specific resources and the failure of using landscape resource data. To produce 576 an LCV map, a fundamental landscape type map was constructed using land cover and landform 577 data. Land cover and landform are critical variables in this study to produce landscape types 578 representing landscape as a socio-ecological system with a mosaic of natural and human579 modified ecosystems. In this context, land cover data are considered an extended interpretation as they reflect human influence on the landscape. However, landform data were used as it has a great impact on natural processes of landscape, providing distinct visual borders and homogeneous visual shaping throughout their expanse. After production of a landscape type map, the LCV for each landscape type was assigned by a group of landscape experts. The purpose of assigning an LCV in this study was to verify areas in need of conservation-oriented management, areas that need to be aware of negative impacts of development, and, most importantly, susceptible areas that require more careful and constant monitoring due to the coexistence of landscape types with high LCV and low LCV.

In addition, our developed process can be applied to any study site. Using fundamental variables to produce landscape type maps and an LCV allows users to extend beyond identifying landscape features, patterns, and susceptible areas for enhanced management in a given region.

591 This instead enables them to compare regions and create macroscopic landscape analyses at the national scale. If additional variables were included to account for diverse present-day ecology, culture, and cognition, we expect that it would present more objective and logical landscape 594 management and policies. 


\section{References}

597 Andersson L, and Löfgren R. 2000. Sydsvenska lövskogar och andra lövbärande marker:

598

599

600

601

602

603

604

605

606

607

608

609

610

611

612

613

614

615

616

617

618

619

620

621

622

623

624

625

626

627

628

629

630

631

632

633

634

635

636

637

638

639 kriterier för naturvärdering, skydd och skötsel: Naturvårdsverket.

Aoki Y. 2015. A historical review of landscape appreciation studies published in English journals until 2013. Environmental Information Science 43:115-124.

Astegiano J, Guimarães Jr PR, Cheptou P-O, Vidal MM, Mandai CY, Ashworth L, and Massol F. 2015. Persistence of plants and pollinators in the face of habitat loss: insights from trait-based metacommunity models. Advances in Ecological Research: Elsevier, 201257.

Baartman JE, Temme AJ, and Saco PM. 2018. The effect of landform variation on vegetation patterning and related sediment dynamics. Earth Surface Processes and Landforms 43:2121-2135.

Brabyn LJJoem. 2005. Solutions for characterising natural landscapes in New Zealand using geographical information systems. 76:23-34.

Brown G, and Raymond C. 2007. The relationship between place attachment and landscape values: Toward mapping place attachment. Applied geography 27:89-111.

Brown G, and Reed P. 2000. Validation of a forest values typology for use in national forest planning. Forest science 46:240-247.

Burkhard B, Kroll F, Müller F, and Windhorst W. 2009. Landscapes' capacities to provide ecosystem services-a concept for land-cover based assessments. Landscape Online 15:122.

Cha J, Cho K, and Kim C. 2019. The 5th national natrual environment survey guidelines. Seocheon, Korea: National Institute of Ecology. p 135.

Conacher A, and Dalrymple J. 1977. The nine unit landsurface model: an approach to pedogeomorphic research. GEODERMA 18:127-144.

Dalrymple J. 1968. A hypothetical nine unit landsurface model. Zeitschrift für Geomorphologie 12:60-76.

Denier L, Scherr S, Shames S, Chatterton P, Hovani L, and Stam N. 2015. The Little Sustainable Landscapes Book: Achieving sustainable development through integrated landscape management. Oxford: Global Canopy Programme.

Dewan AM, and Yamaguchi Y. 2009. Land use and land cover change in Greater Dhaka, Bangladesh: Using remote sensing to promote sustainable urbanization. Applied geography 29:390-401.

Dewan AM, Yamaguchi Y, and Rahman MZ. 2012. Dynamics of land use/cover changes and the analysis of landscape fragmentation in Dhaka Metropolitan, Bangladesh. GeoJournal 77:315-330.

Erikstad L, Lindblom I, Jerpåsen G, Hanssen MA, Bekkby T, Stabbetorp O, and Bakkestuen V. 2008. Environmental value assessment in a multidisciplinary EIA setting. Environmental Impact Assessment Review 28:131-143.

Evans J. 2020. spatialEco: Spatial Analysis and Modelling Utilities. R package version 1.3-4. Available at https://github.com/jeffreyevans/spatialEco.

Fairclough G, and Macinnes L. 2003. Landscape character assessment guidance for England and Scotland. Topic paper 5: Understanding historic landscape character. Scottish Natural Heritage and The Countryside Agency, Edinburgh. 
640 Frank S, Fürst C, Koschke L, and Makeschin F. 2012. A contribution towards a transfer of the 641 ecosystem service concept to landscape planning using landscape metrics. Ecological $642 \quad$ indicators 21:30-38.

643 Frank S, Fürst C, Koschke L, Witt A, and Makeschin F. 2013. Assessment of landscape

644

645

646

647

648

649

650

651

652

653

654

655

656

657

658

659

660

661

662

663

664

665

666

667

668

669

670

671

672

673

674

675 aesthetics - Validation of a landscape metrics-based assessment by visual estimation of the scenic beauty. Ecological indicators 32:222-231.

Fry GL. 2001. Multifunctional landscapes - towards transdisciplinary research. Landscape urban planning 57:159-168.

Golley FB. 1993. A history of the ecosystem concept in ecology: more than the sum of the parts: Yale University Press.

Gonggrijp G. 1981. Earth-science conservation: no science without conservation. Geologie and Mining 60:433-445.

Groom G. 2005. Methodological review of existing classifications. European Landscape Character Areas-Typologies, Cartography and Indicators for the Assessment of Sustainable Landscapes: Wageningen: Landscape Europe Secretariat, 32-45.

Hansen AJ, and DeFries R. 2007. Ecological mechanisms linking protected areas to surrounding lands. Ecological applications 17:974-988.

Harper C, Crow T, Cooksey R, Hoover A, Butler B, and Flather C. 2006. Cooperating across boundaries: Partnerships to conserve open space in rural America. In: Service UF, editor. Washington, DC: USDA. p 49.

Hockings M, Stolton S, and Leverington F. 2006. Evaluating Effectiveness: A framework for assessing management effectiveness of protected areas: IUCN.

Holt-Jensen A. 2018. Geography: history and concepts: Sage.

Ioannidou D, Nikias V, Brière R, Zerbi S, and Habert G. 2015. Land-cover-based indicator to assess the accessibility of resources used in the construction sector. Resources, Conservation and Recycling 94:80-91.

Jeon Y, Han S, and Kim Y. 2013. Preservation and Practical Application of Hwayang-Gugok in Songnisan National Park. The Korean Association of Regional Geographers 19:683-696.

Jones DA, Hansen AJ, Bly K, Doherty K, Verschuyl JP, Paugh JI, Carle R, and Story SJ. 2009. Monitoring land use and cover around parks: A conceptual approach. Remote sensing of environment

113:1346-1356.

Jones K. 2008. Importance of land cover and biophysical data in landscape-based environmental assessments. North America Land Cover Summit. Washington, DC: Association of American Geographers, 249.

676

677

678

679

680

681

682

683

684

Ju S, and Woo K. 2019. A new approach for the geological assessment for geoheritage conservation in Korea. The Geological Society of Korea 55:149-163.

Jung H. 2018. A systemic landscape management through landscape characterization of the United Kingdom. Architecutre and Urban spaces 31:35-43.

Kang H-G, Kim C-S, and Kim E-S. 2013. Human influence, regeneration, and conservation of the Gotjawal forests in Jeju Island, Korea. Marine Island Cultures 2:85-92.

Kaplan R. 1990. The perception of landscape style: a cross-cultural comparison. Landscape urban planning 19:251-262.

Kim C-W. 2009. Geomorphological Landscapes Research and Utilization of DMZ and Borderland. Korean association of regional geographers 15:317-327.

PeerJ reviewing PDF | (2020:10:53761:2:0:NEW 13 Apr 2021) 
685

686

687

688

689

690

691

692

693

694

695

696

697

698

699

700

701

702

703

704

705

706

707

708

709

710

711

712

713

714

715

716

717

718

719

720

721

722

723

724

725

726

727

728

729

Koschke L, Fürst C, Frank S, and Makeschin F. 2012. A multi-criteria approach for an integrated land-cover-based assessment of ecosystem services provision to support landscape planning. Ecological indicators 21:54-66.

LaGro Jr James A. 1996. Designing without nature: unsewered residential development in rural Wisconsin. Landscape urban planning 35:1-9.

Lee K. 2018. A current status of National Landscape policy and its future. Architecture and Urban spaces 31:12-18.

Lee S-B. 2017. Geological Heritage Value and Appropriate Conservation/Utilization of the Seokgaejae Early Paleozoic Sedimentary Stratal Section. Korean Journal of Cultural Heritage Studies 50:126-145.

Li T, Shilling F, Thorne J, Li F, Schott H, Boynton R, and Berry AM. 2010. Fragmentation of China's landscape by roads and urban areas. Landscape Ecology 25:839-853.

Lukenbach M, Spencer C, Mendoza C, Devito K, Landhäusser S, and Carey S. 2019. Evaluating how landform design and soil covers influence groundwater recharge in a reclaimed watershed. Water Resources Research 55:6464-6481.

Martín Duque JF, Pedraza Gilsanz Jd, Sanz Santos MA, Bodoque del Pozo JM, Godfrey AE, Díez Herrero A, and Carrasco González RM. 2003. Environmental Assessment: Landform Classification for Land Use Planning in Developed Areas: An Example in Segovia Province (Central Spain). Environmental management 32:488-498.

McKinney ML. 2002. Urbanization, Biodiversity, and ConservationThe impacts of urbanization on native species are poorly studied, but educating a highly urbanized human population about these impacts can greatly improve species conservation in all ecosystems. Bioscience 52:883-890.

Mehmood F, Ahmad S, and Kim D. 2019. Design and Development of a Real-Time Optimal Route Recommendation System Using Big Data for Tourists in Jeju Island. Electronics 8:506.

Metcalfe P, Beven K, and Freer J. 2018. dynatopmodel: Implementation of the dynamic topmodel hydrological model. Available at https//cran. $r$-project. org/package $=$ dynatopmodel.

Mihu-Pintilie A, and Nicu IC. 2019. GIS-based Landform Classification of Eneolithic Archaeological Sites in the Plateau-plain Transition Zone (NE Romania): Habitation Practices vs. Flood Hazard Perception. Remote Sensing 11:915.

Millspaugh J, and Thompson F. 2009. Social and economic considerations for planning wildlife conservation in large landscapes. Models for planning wildlife conservation in large landscapes Burlington, MA: Elsevier, 123-152.

Mücher CA. 2009. Geo-spatial modelling and monitoring of European landscapes and habitats using remote sensing and field surveys. Wageningen University, NL.

Mücher CA, Klijn JA, Wascher DM, and Schaminée JHJEi. 2010. A new European Landscape Classification (LANMAP): A transparent, flexible and user-oriented methodology to distinguish landscapes. 10:87-103.

Nakamura Y. 1982. Funkeigaku Nyumon(Beginning of the Study on Landscape Appreciation). Tokyo: Chuo-kouron Sha.

Nam H-Y, Kim E-M, Choi C-Y, and Kang C-W. 2019. Avifauna of Gungdae Oreum and its seasonal changes in the Jeju Eastern Oreum Group in Jeju Island, Korea. Asia-Pacific Biodiversity 12:515-521. 
730

731

732

733

734

735

736

737

738

739

740

741

742

743

744

745

746

747

748

749

750

751

752

753

754

755

756

757

758

759

760

761

762

763

764

765

766

767

768

769

770

771

772

773

774

775

Opdam P, van Apeldoorn R, Schotman A, and Kalkhoven J. 1993. Population responses to landscape fragmentation. Landscape ecology of a stressed environment: Springer, 147171.

Park S-J. 2004. A Geomorphological Classification System to Chatacterize Ecological Processes over the Landscape. Korean Geographical Society 39:495-513.

Ratcliffe D. 2012. A nature conservation review: volume 1: the selection of biological sites of national importance to nature conservation in Britain: Cambridge University Press.

Risbøl O, Vaage J, Ramstad M, Narmo LE, and Høgseth HB. 2000. Kulturminner og kulturmiljø i Gråfjell, Regionfelt Østlandet, Åmot kommune i Hedmark: arkeologiske registreringer 1999, fase 1. Norwegian Institute for Cultural Heritage Research.

Rudberg S, and Sundborg Å. 1975. Vattendragen i norra Norrland. Naturgeogr. Inst. Uppsala Vattendragen i norra Norrland.

Saura S, Bertzky B, Bastin L, Battistella L, Mandrici A, and Dubois G. 2019. Global trends in protected area connectivity from 2010 to 2018. Biological conservation 238:108183.

Sayer J, Sunderland T, Ghazoul J, Pfund J-L, Sheil D, Meijaard E, Venter M, Boedhihartono AK, Day M, and Garcia C. 2013. Ten principles for a landscape approach to reconciling agriculture, conservation, and other competing land uses. Proceedings of the national academy of sciences 110:8349-8356.

Sayre R, Dangermond J, Frye C, Vaughan R, Aniello P, Breyer S, Cribbs D, Hopkins D, Nauman R, and Derrenbacher W. 2014. A new map of global ecological land units-an ecophysiographic stratification approach. Washington, DC: Association of American Geographers.

Scherr S, and Wertz L. 2019. Integrated landscape approach to using restoration to help achieve multiple SDGs. Land Restoration for Achieving the Sustainable Development Goals: An International Resource Panel Think Piece: United Nations Environment Programme, 125.

Selman P. 2006. Planning at the landscape scale. Abingdon, Oxon: Routledge.

Seo J-C. 2013. Characteristics of the coastal landforms in Yeonpyeong Island. Korean association of regional geographers 19:223-233.

Simensen T, Halvorsen R, and Erikstad L. 2018. Methods for landscape characterisation and mapping: A systematic review. Land use policy 75:557-569.

Smith PG, and Theberge JB. 1986. A review of criteria for evaluating natural areas. Environmental management 10:715-734.

Solecka I. 2018. The use of landscape value assessment in spatial planning and sustainable land management - a review. Landscape Research 44:966-981.

Su S, Luo F, Mai G, and Wang Y. 2014. Farmland fragmentation due to anthropogenic activity in rapidly developing region. Agricultural Systems 131:87-93.

Swanson F, Kratz T, Caine N, and Woodmansee R. 1988. Landform effects on ecosystem patterns and processes. Bioscience 38:92-98.

Tudor C. 2014. An approach to landscape character assessment. Natural England. p 56.

UNEP-WCMC. 2020. Protected Planet: Aichi Target 11 Dashboard. Available at https://www.protectedplanet.net/target-11-dashboard (accessed 27 August 2020).

Utredninger NO. 1983. Naturfaglige verdier og vassdragsvern. Norge Offentlige Utredninger. $p$ 376.

Walz U, and Stein C. 2014. Indicators of hemeroby for the monitoring of landscapes in Germany. Journal for Nature Conservation 22:279-289.

PeerJ reviewing PDF | (2020:10:53761:2:0:NEW 13 Apr 2021) 
776 Wascher DM. 2005. European landscape character areas: typologies, cartography and indicators

777 for the assessment of sustainable landscapes. Wageningen University \& Research:

$778 \quad$ Landscape Europe. p 148.

779 Woo KS, Sohn YK, Yoon SH, San Ahn U, and Spate A. 2013. Jeju Island Geopark-a volcanic

$780 \quad$ wonder of Korea: Springer-Verlag Berlin Heidelberg.

781 Zonneveld I. 1989. The land unit - a fundamental concept in landscape ecology, and its

$782 \quad$ applications. Landscape Ecology 3:67-86.

783 Zube EH. 1987. Perceived land use patterns and landscape values. Landscape Ecology 1:37-45.

784 Zube EH, Sell JL, and Taylor JG. 1982. Landscape perception: research, application and theory.

785

786

787 Supplemental Information

788 Supplemental Table S1::

789 Supplemental Table S2.:

790 Supplemental Table S3:

791 Supplemental Figure S1.: 
Figure 1

Study site, Jeju Island, Korea, and its protected areas.

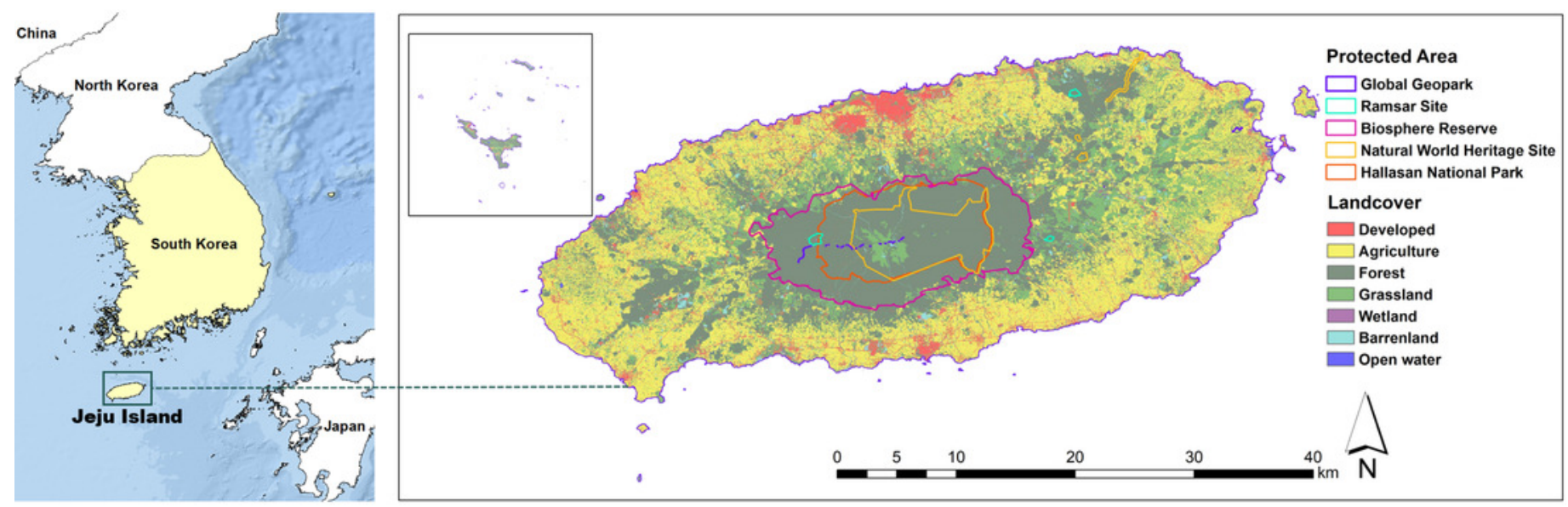


Figure 2

Landform re-classification based on the Nine-Unit Landscape Model (NULM) (Park 2004)

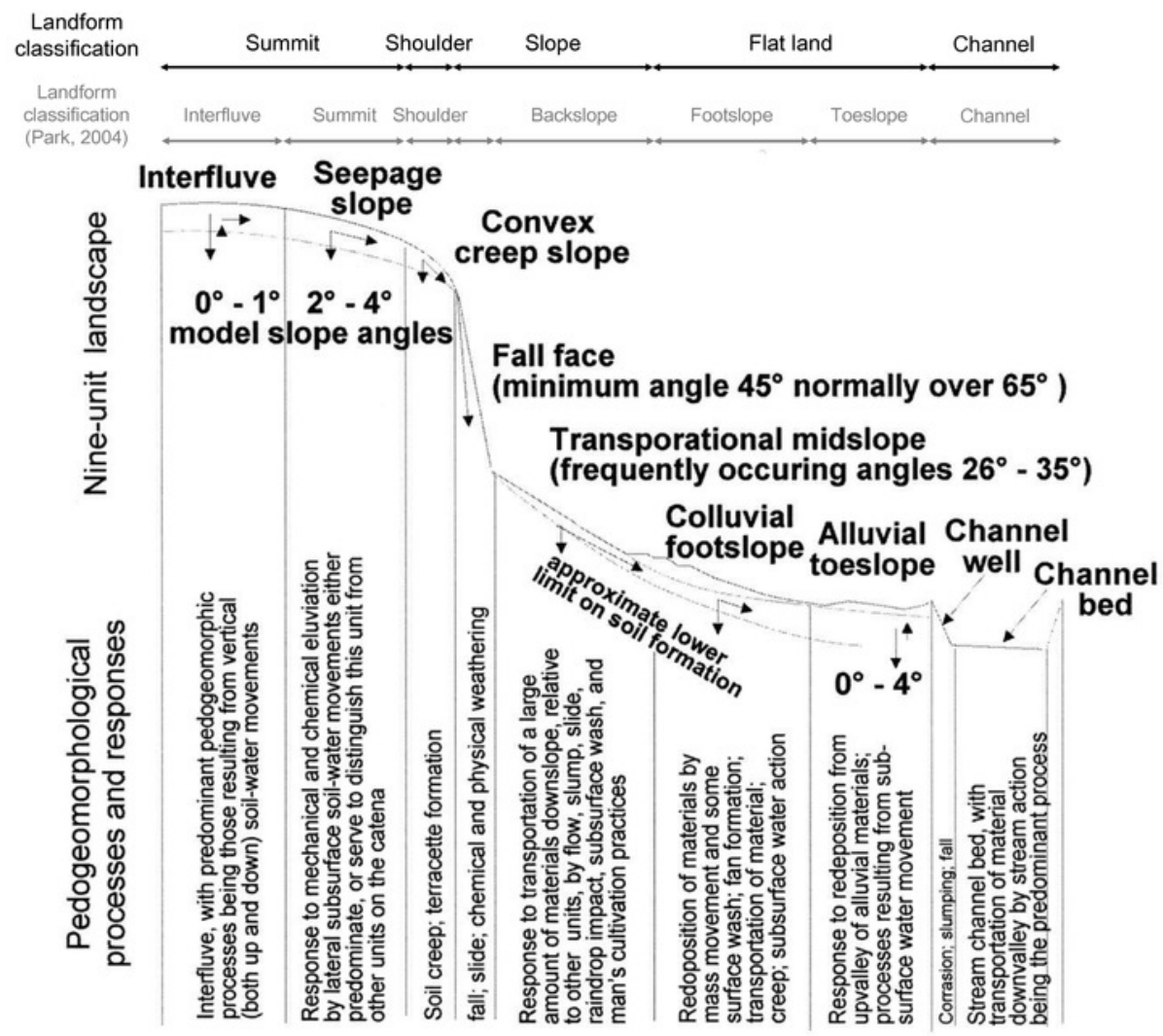


Figure 3

Landscape Conservation Value generation process 

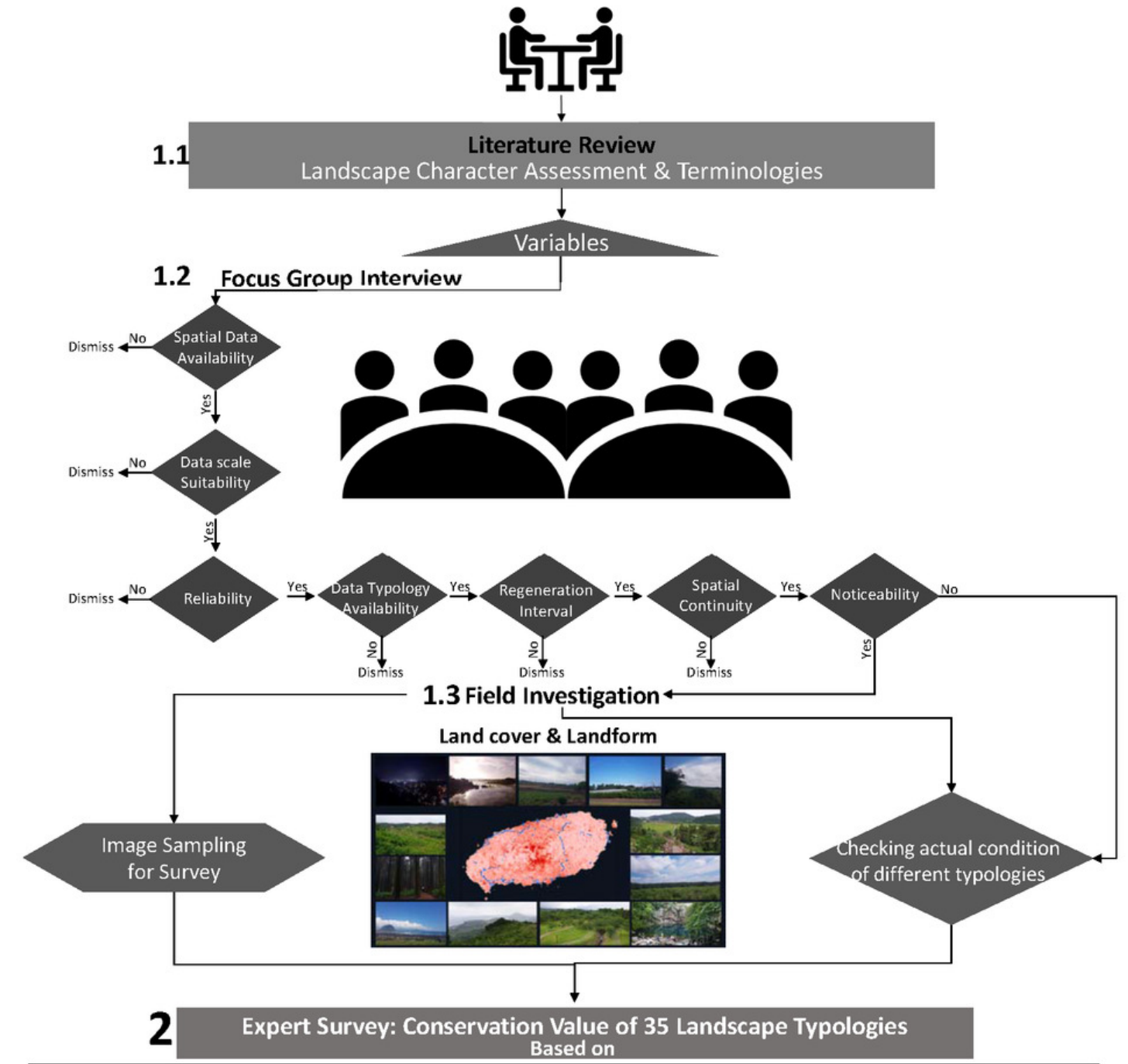

Land cover) Landform
Evaluation of classifications of
individual feature separately
considering both biophysical and
cultural aspects based on expert's
experience
Based on

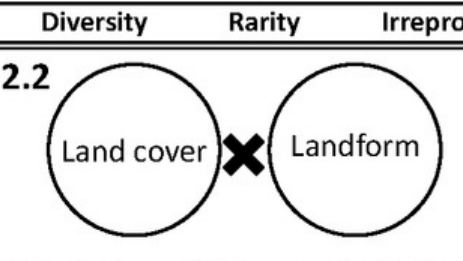

Calculation of the result derived from the $1^{\text {st }}$ expert survey to propose draft of conservation value of landscape types

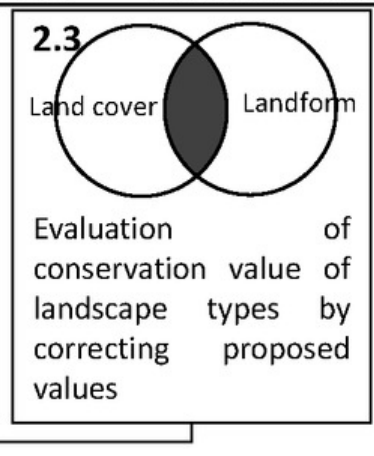

Construction of Matrix 


\section{Figure 4}

\section{Designated areas of Jeju Island}

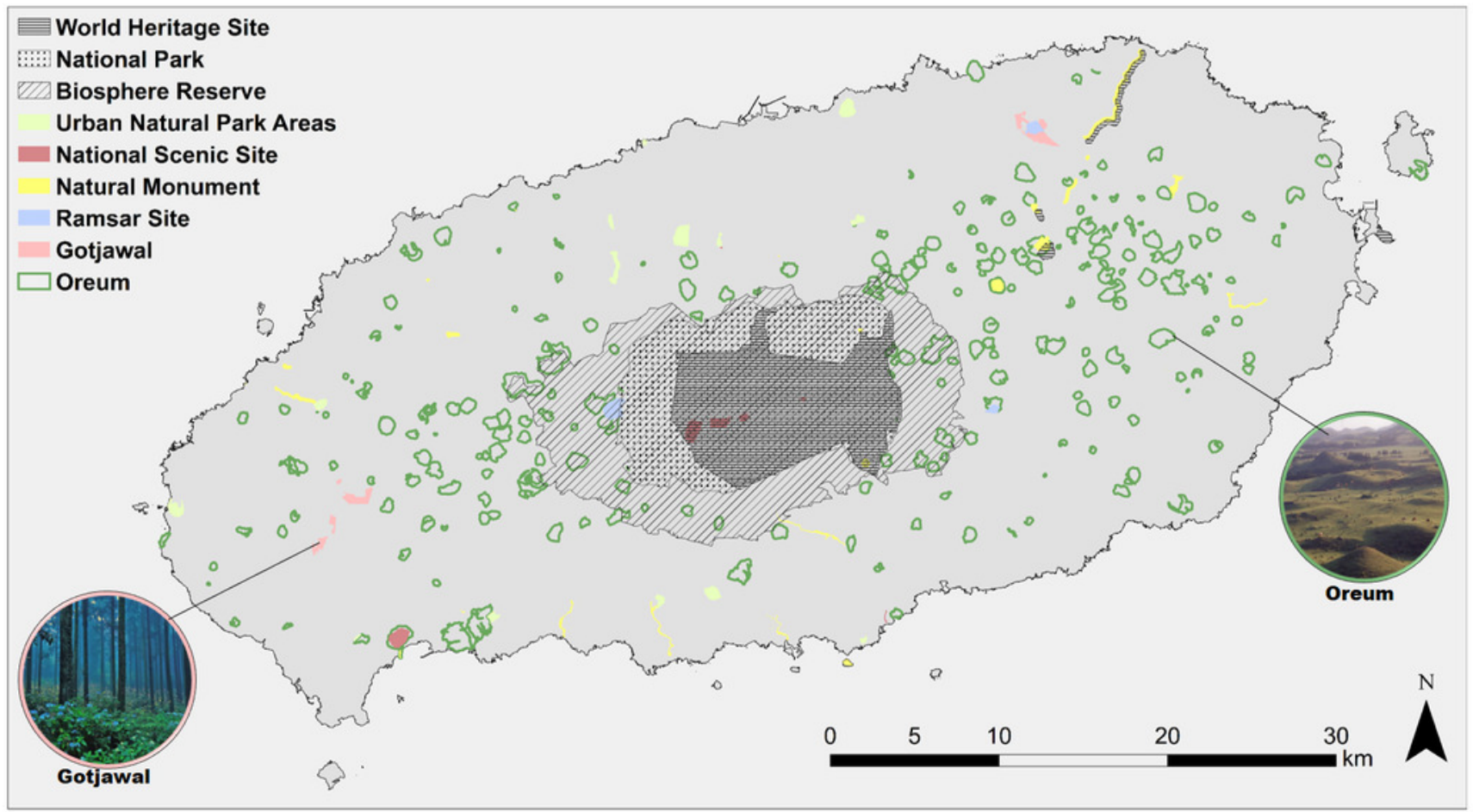


Figure 5

Large class land cover map of the research site

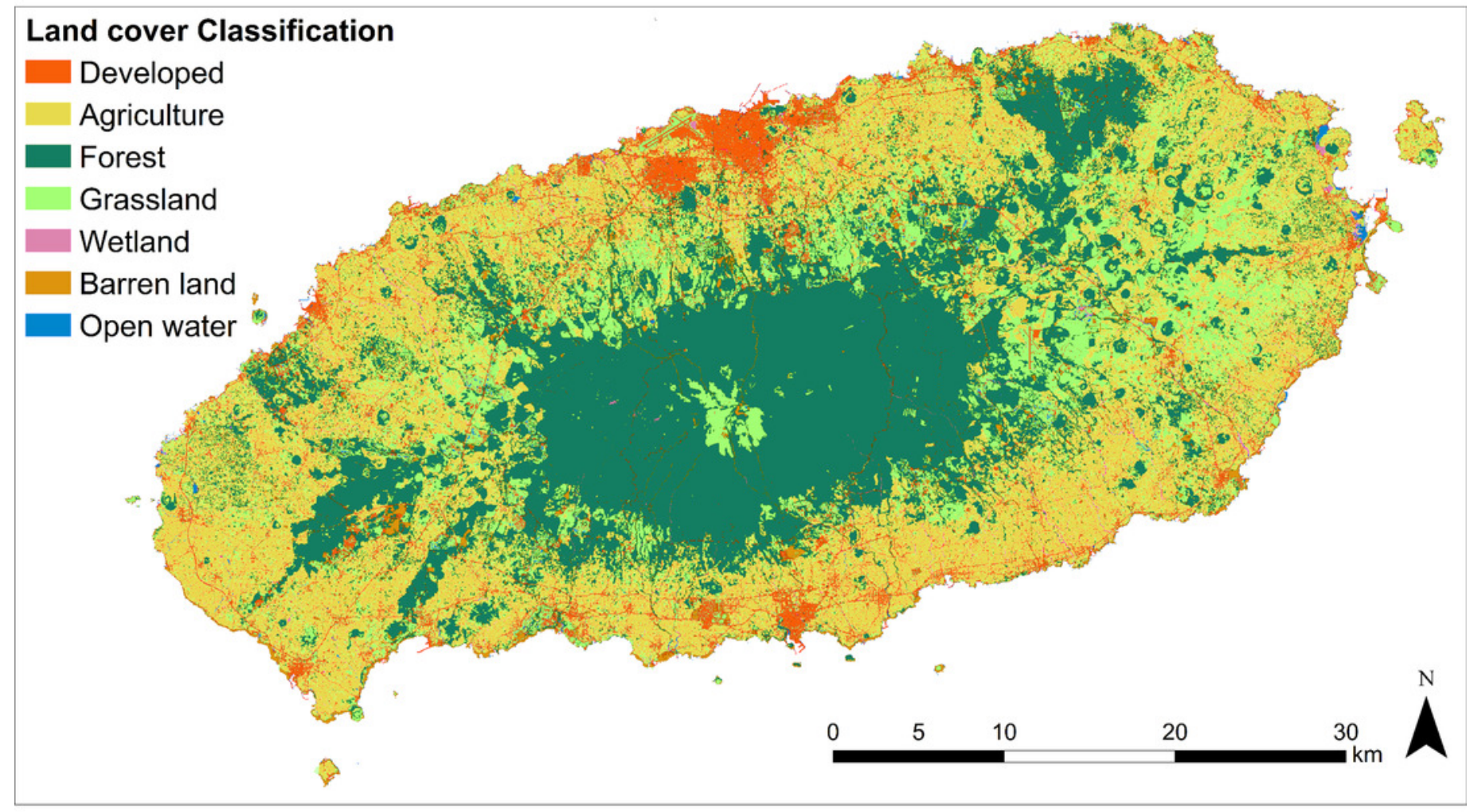




\section{Figure 6}

Landform re-classification of the research site based on the Nine-Unit Landscape

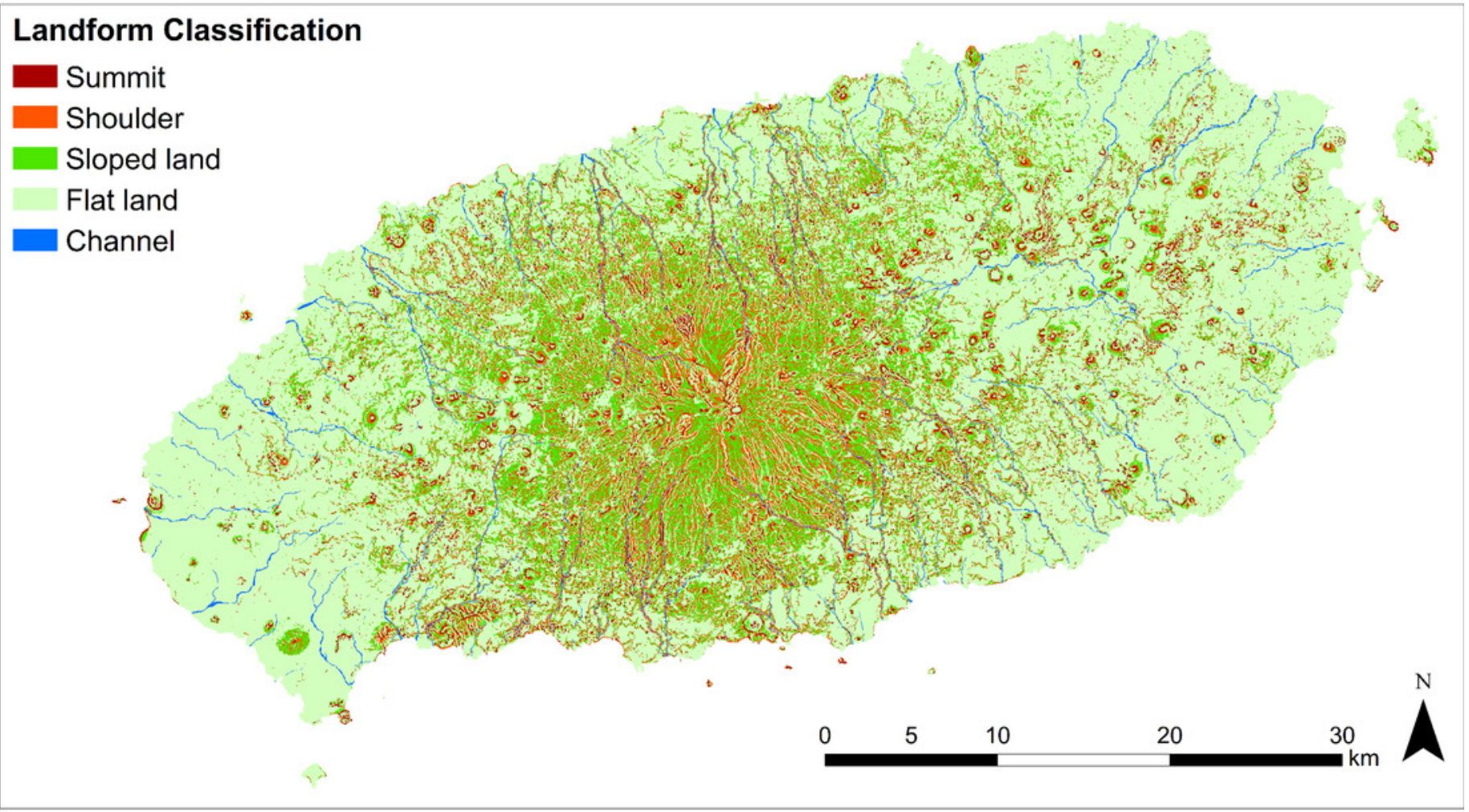


Figure 7

Proportion of each landscape type within the study site

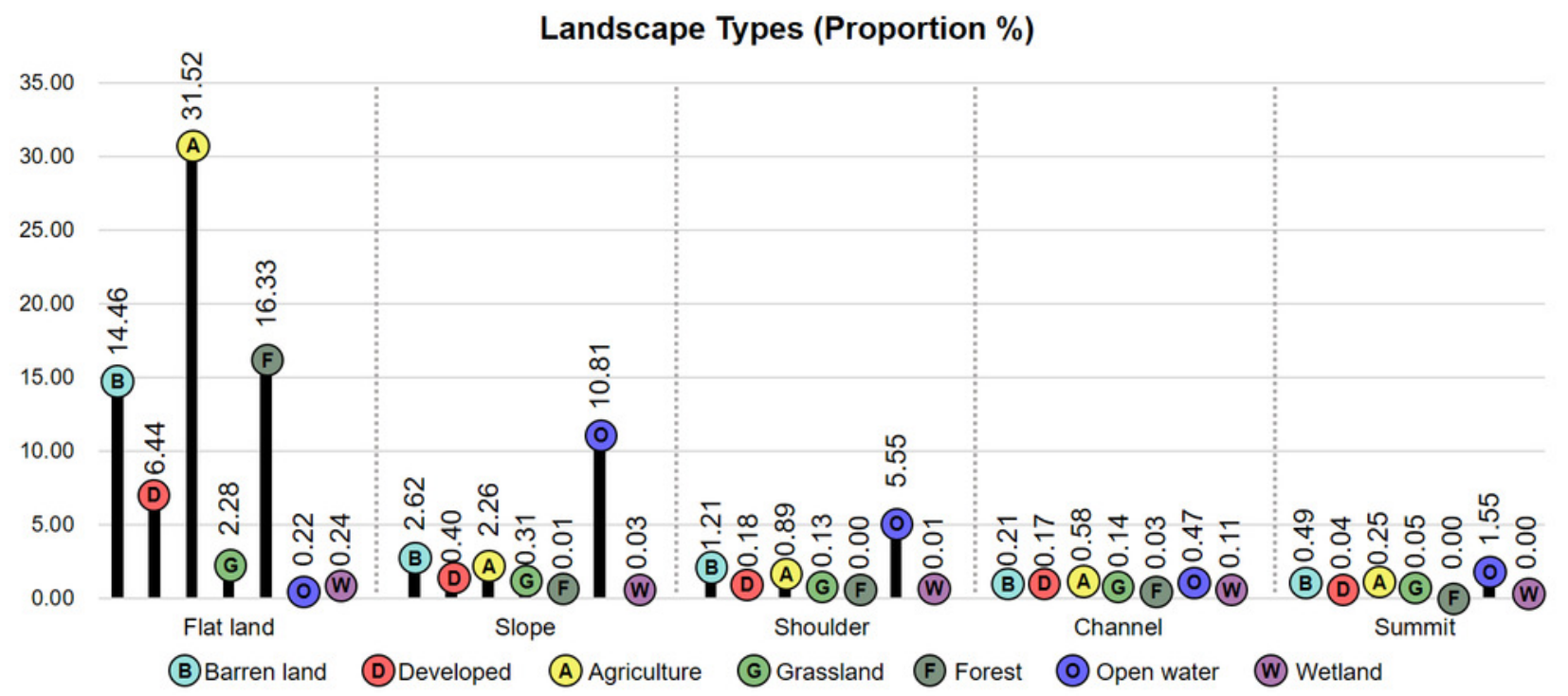


Figure 8

\section{Landscape type derived from Landform and Land cover}

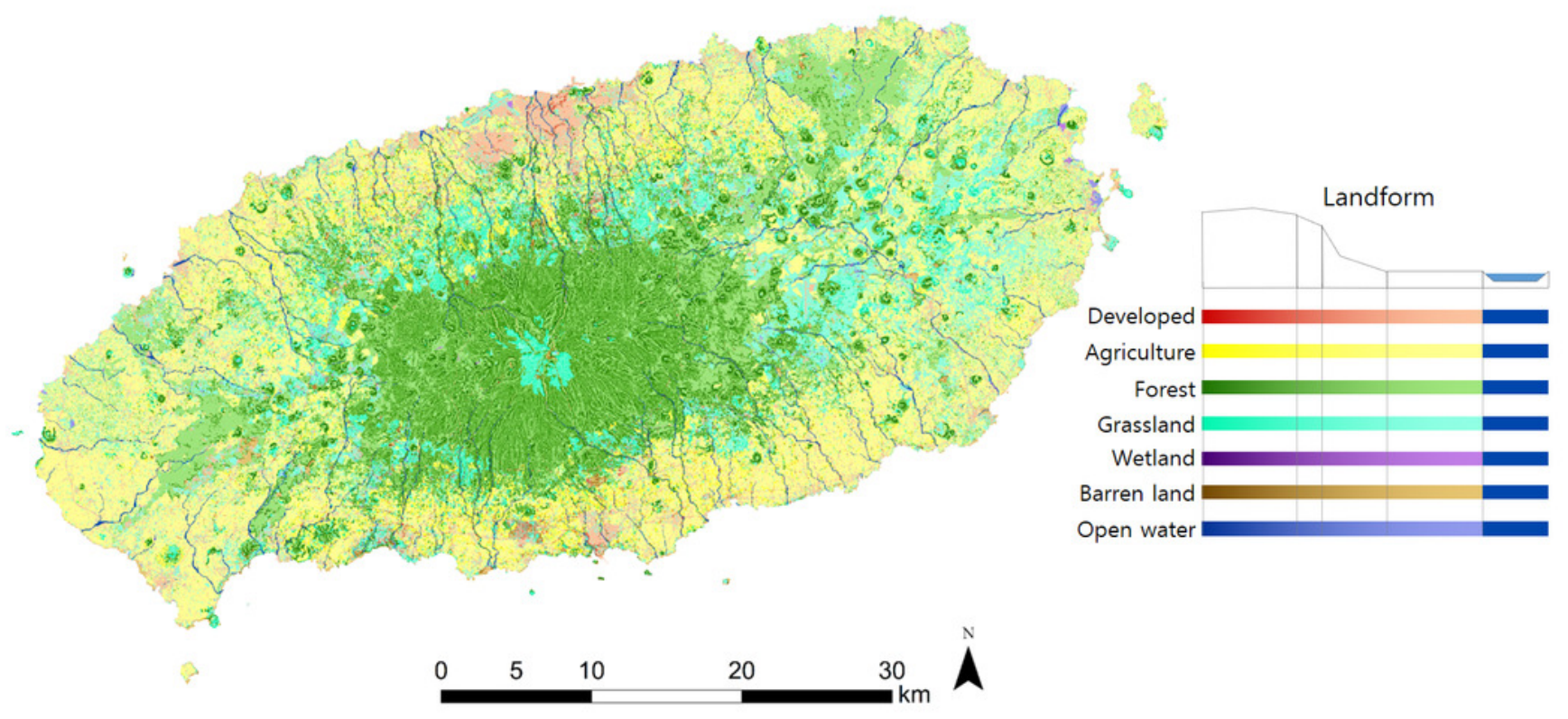




\section{Figure 9}

Landscape Conservation Value map with multiple layers of designated areas (1-Oreum; 2-Urban Natural Park Areas; 3-National Park; 4-Biosphere Reserve; 5-Gotjawal; 6-Scenic Site; 7-World Heritage Site; 8-Ramsar Site; 9-Natural Monument)

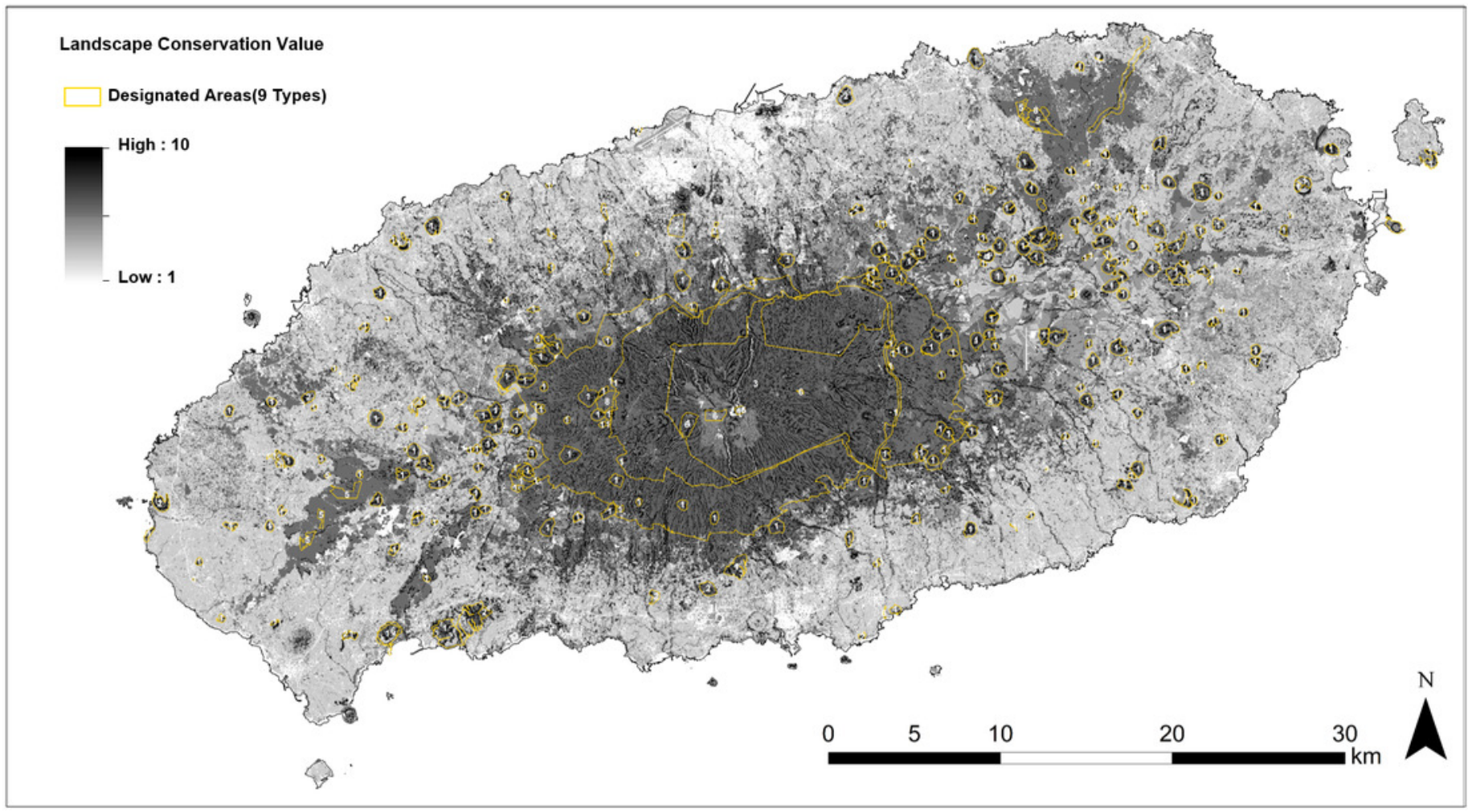


Figure 10

Map of susceptible area based on heterogeneity of landscape conservation values

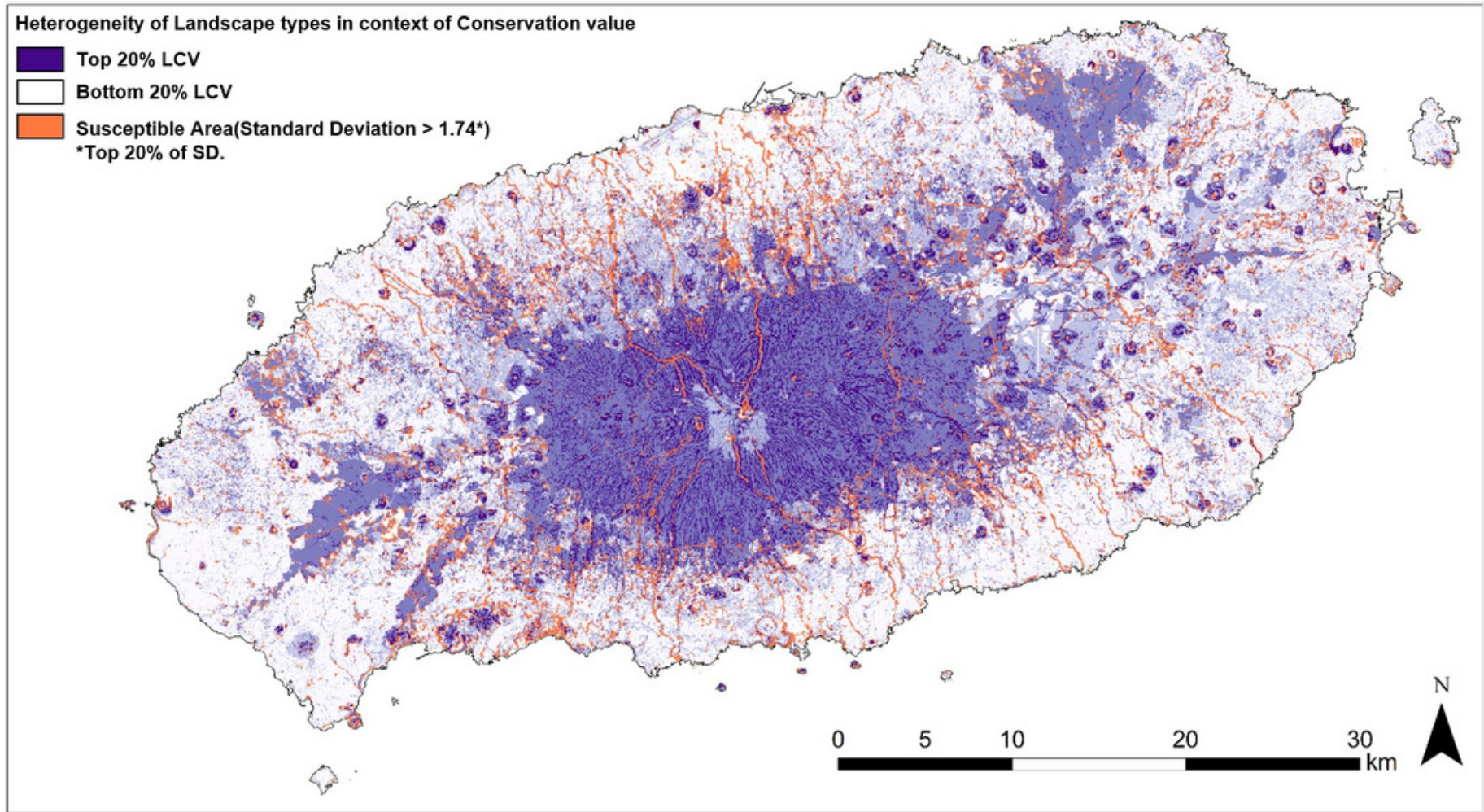




\section{Box 1 (on next page)}

Value criteria of six factors derived from the geomorphological landscape section of the National Natural Environment Survey guidelines used in this research(Cha et al. 2019) 
Box 1. Value criteria of six factors derived from the geomorphological landscape section of the National Natural Environment Survey guidelines used in this research (Cha et al. 2019)

\section{Key Definitions of terms related to landscape used in this research}

\section{Landscape}

- Landscape is comprised of diverse physical products that result from interactions between different phenomena and human behaviors within an ecosystem.

- Landscape is a single system perceived and recognized by humans which comprises natural scientific, social scientific, and anthropological dimensions (Zonneveld 1989; Zube et al. 1982) and is influenced by diverse land use approaches such as ecological, historical, political, economic, and cultural processes and activities (Denier et al. 2015).

\section{Landscape Type}

- Fundamental framework for prioritization of susceptible areas based on a landscape conservation value assigned by landscape experts for enhanced landscape management.

- It is the properties of landscapes which consider biophysical dimensions, human-aesthetic dimensions, user participation, and policy dimension (Groom 2005).

- In this study, landscape types are classified based on a combination of 5 different landform and 7 different land cover types.

\section{Landscape Conservation Value (LCV)}

- $\quad$ LCV is the general idea and goal of prioritizing conservation efforts to landscape types based on six factors described below. More values are added to landscape types with cultural and natural aspects that are likely to become damaged and fragmented when exposed to human induced activities.

\section{Meanings and Value criteria of six factors}

- Representativeness: Noticeability of characteristics and form of specific landscape. More values are added as the landscape clearly shows the cause of development and formation of the region.

- Specificity: A sign of unique natural phenomena and a developing process. More values are added if the landscape has a distinctive formation and structural materials.

- Diversity: A degree of how different landforms are scattered within a region. More values are added if there are diverse components of landscape clustered together.

- Rarity: A relative scarcity of landforms and landscape components due to regional characteristics. More values are added if the landscape only appears in a specific region.

- Irreproducibility: Vulnerability of the landscape or landform when exposed to natural or artificial environmental change and degree of difficulty for restoration. More values are added if the landscape seems to be sensitive to external factors and is associated with previous climate or environmental change.

- Educational Value: Possibility of the object to be used for a research and environmental education. More values are added if the landscape provides usability for a research and provides a great accessibility 


\section{Table $\mathbf{1}$ (on next page)}

Similarities between the land cover classification used in this study and the Coordination of Information on the Environment (CORINE) land cover classification

${ }^{1}$ CORINE classification proposed by Bossard et al. (Bossard et al. 2000) ; ${ }^{2}$ Land Cover classification proposed by the Korean Ministry of Environment 
1 Table 1:

2 Similarities between the land cover classification used in this study and the Coordination

3 of Information on the Environment (CORINE) land cover classification

\begin{tabular}{lll}
\hline \multicolumn{2}{c}{ Corine Land Cover ${ }^{1}$} & \multicolumn{1}{c}{ Land } \\
\hline & & 1. Developed area \\
1. & Artificial surfaces & 2. Agricultural area \\
2. & Agricultural areas & 3. Forest area \\
3. & Forest and seminatural areas & 4. Grassland \\
4. & Wetlands & 5. Wetland \\
5. & Water bodies & 6. Barren land \\
& & 7. Open water
\end{tabular}

$4{ }^{1}$ CORINE classification proposed by Bossard et al. (Bossard et al. 2000); ${ }^{2}$ Land Cover classification proposed by the Korean

5 Ministry of Environment 


\section{Table 2 (on next page)}

Final Landscape Conservation Value Matrix based on the results of the 2nd Expert Survey with simplified Landform classification and changed Land cover class order 
1 Table 2:

2 Final Landscape Conservation Value Matrix based on the results of the 2nd Expert

3 Survey with simplified Landform classification and changed Land cover class order

\begin{tabular}{|c|c|c|c|c|c|}
\hline \multirow{2}{*}{ Land Cover } & \multirow[b]{2}{*}{ Flat land } & \multirow[b]{2}{*}{ Slope } & \multirow[b]{2}{*}{ Shoulder } & \multirow[b]{2}{*}{ Channel } & \multirow[b]{2}{*}{ Summit } \\
\hline & & & & & \\
\hline Barren land & 1.00 & 1.59 & 1.93 & 2.52 & 3.02 \\
\hline Developed & 1.43 & 1.68 & 2.18 & 2.43 & 3.45 \\
\hline Agriculture & 2.86 & 3.27 & 4.54 & 4.54 & 5.79 \\
\hline Grassland & 4.20 & 4.79 & 5.96 & 6.38 & 7.98 \\
\hline Forest & 5.63 & 5.96 & 7.64 & 8.23 & 9.41 \\
\hline Open water & 5.88 & 6.64 & 8.14 & 8.39 & 10.00 \\
\hline Wetland & 6.21 & 6.46 & 7.73 & 8.57 & 10.00 \\
\hline
\end{tabular}

4 


\section{Table 3(on next page)}

Mean landscape conservation value for the protected regions on Jeju Island

${ }^{1}$ LCV stands for Landscape Conservation Value 
1 Table 3:

2 Mean landscape conservation value for the protected regions on Jeju Island.

\begin{tabular}{cccc}
\hline Designation & Area $\mathbf{( k m}^{\mathbf{2}} \mathbf{)}$ & Mean $\mathbf{L C V}$ & Std. Deviation \\
\hline World Natural Heritage Site & 2.46 & 5.40 & 1.67 \\
National Park & 152.82 & 6.41 & 1.18 \\
Biosphere Reserve & 119.32 & 6.19 & 1.17 \\
Urban Natural Park Areas & 5.65 & 5.64 & 2.14 \\
National Scenic Site & 1.06 & 5.81 & 2.18 \\
Natural Monument & 6.90 & 5.21 & 1.89 \\
Ramsar Site & 1.88 & 6.05 & 0.93 \\
Gotjawal & 3.12 & 5.78 & 7.25 \\
Oreum & 81.04 & 6.34 & 1.77 \\
Whole research site & $\mathbf{1 , 8 4 7 . 3 3}$ & $\mathbf{4 . 3 5}$ & $\mathbf{1 . 9 3}$ \\
\hline
\end{tabular}

$3{ }^{1}$ LCV stands for Landscape Conservation Value

4 